\title{
19 Developing the integration of the Chinese Internet and the film industry
}

\author{
Luyao $\mathrm{Li}$
}

The year 2017 was the year of continuous expansion of China's film market. The total box office of China's film market exceeded 55.9 billion yuan. The vigorous development of the film industry has attracted the attention of a group of the major Internet enterprises, such as BAT (Baidu, Alibaba, Tencent). The Internet has reshaped how films are produced, distributed, marketed and screened. On top of that, the Internet has allowed the traditional film industry to be optimized for online interactivity, mobility and fragmentation.

\section{The Internet reshapes the film industry}

With the help of new media, big data and other technologies, the Internet has created full integration of resources. With the increased Internet speed, movies made in the era of digital media have had a bigger impact on the industry than the films made previously. The Internet has reshaped the production mode of domestic films and brings new thinking and a breakthrough in film marketing. The emergence of cross-border capital has also provided an important impetus for the development of domestic films. With content as its core, the film industry integrates with the Internet industry to produce diversified and precise marketing, quickly gathers core users and spreads to other audiences, drives the derivatives market, and gradually forms the "industrial chain" of domestic films.

\section{The Internet reshapes the film production mode}

In the traditional film production mode, script creation, team building, actor casting and other preparatory work all centered on the director. Project capital, filming technology, publicity and distribution channels, and other resources are mostly undertaken by enterprises. In such a situation, the traditional film industry formed a film production mode where the company takes the lead, while the director and stars are the center of the production team. In the context of the Internet, the mode for domestic film production has changed dramatically. Internet enterprises have unique advantages in big data 
utilization. Users change from recipients to participants, which makes the slogan "everyone is the director of life" true. It is necessary for the producer to participate deeply from the beginning of production.

We are in a period of social change. Young people are the main force of online consumption, and the mode of consumption directly affects production. Understanding the needs of young people is the key to film production in the Internet era. The user is the market, and the user is the center. The video website is not only the investor, but also the channel and the producer.

\section{The Internet reshapes film distribution}

Traditional methods of film distribution include cinemas, TV stations, film and television companies, etc. With the advent of the Internet, China is the country with the largest change in film distribution mode. The traditional cinema mode is now challenged. Online video websites attract a large number of users by virtue of content diversity, broadcast nonlinearity and portability of the viewing equipment. The numbers of videos on iQiyi, Tencent Video, Sohu Video and other major video websites have increased dramatically. In 2017, video websites became the new battlefield of film distribution with a higher degree of content segmentation. At the same time, with the rapid development of the Internet, and ticketing platforms such as MaoYan movie, Taobao movie and Gewara movie, film distribution has been changed by virtue of the advantages of "data + users." These ticket platforms provide online ticket sales, seat selection, and other services, and change the traditional offline box office recycling mode into an "online + offline" mode, which advances the traditional ticket purchase time before the film is released, causing a change in the film distribution mode.

\section{The Internet reshapes the film marketing mode}

The era of Web 2.0 has given the Internet interaction characteristics. This has become the biggest tool of film marketing in the new media era. The traditional film marketing mode is dominated by advertisements, posters and film press release conferences, which are characterized by high consumption and short duration. In the age of the Internet, Weibo and WeChat are the two social media platforms that are the biggest exporters of movie marketing. Sina Weibo has set up an interactive platform between the film creation team and the film audience, with 297.5 billion film articles in 2015 . Weibo platform has become a huge data platform, reaching users through precision marketing. The movie Monkey King: Hero Is Back was effectively marketed with the help of Weibo during its release. With the help of "tap water," the final box office reached 950 million yuan, achieving a box office reversal. Unlike Weibo, WeChat users have strong connectivity. 
On the one hand, all major cinemas have set up a public WeChat account to convey the latest movie information to the users. On the other hand, the new applications of WeChat application and expression pack provide more channels for film marketing. Taking Monster Hunt 2 which was released on the first day of the Spring Festival in 2018 as an example, WeChat formed a closed-loop marketing chain from watching movies to buying ticket apps. During the Spring Festival, the New Year expression pack of Monster Hunt was favored by users.

\section{The Internet reshapes film screening}

Cinema is the main channel for Chinese films. But only less than a third of the films produced in China are shown in theaters every year. This means that the remaining films do not reach audiences or are put into the industrial chain in order to achieve profits. With the development of network technology, mobile communication technology, and new business models, online video websites are becoming a comprehensive platform integrating content production, marketing, promotion and broadcasting. Online paid viewing is increasingly being accepted by more users. Personal computers and mobile devices become the realization mode of multi-channel projection after the cinema screen. In future, home terminals and intelligent hardware terminals will become the next preemptive position.

As of December 2017, the number of Internet users in China reached 772 million, while the proportion of young Internet users reached 500 million, which accounts for more than 70 percent of the total number of Internet users. Most of the paying customers of video websites are young users, aged between 19 and 30 years. The group of young users is huge; they have the highest requirements for content and a strong willingness to pay. The data show that in 2016, the number of paid users reached 74.7 million, and the payment penetration rate was only 13.7 percent. In 2017 , the number of paying customers reached 112 million. It is expected that in the next three years, the number of paying customers will exceed 250 million, and the payment penetration rate will reach 47.3 percent. Of them, the market size of paying customers will reach 45.846 billion yuan. If unforeseen factors are included, the market size can reach 60 billion yuan or even 100 billion yuan.

\section{How to integrate the film industry and the Internet enterprises represented by BAT}

In recent years, a large number of Internet enterprises represented by BAT have begun to take part in the film industry, relying on a large number of user groups to achieve seamless docking between film products and target users, and penetrating into all aspects of the film industry chain. The Internet can be seen in script selection, fund raising, film shooting, distribution, screening, publicity, etc. 


\section{Film production data}

Big data have changed the production mode of Chinese films. In the Internet age, every click is network flow, every network flow is data, and every bit of data is the label of users, which represents the value pursuit and aesthetic standards of users. In terms of creation, users have changed from one-way receivers in the era of traditional films to being active participants in the market. With the rapid development of Internet technology, when the film is examined by the investors, it not only requires the attraction of the script content but also requires the demand summary and revenue and expenditure estimation after big data analysis. With specific data support, it is more persuasive in negotiation and cooperation. Moreover, because the high-quality content itself accumulates a large number of fans, in addition to the audience, who can be directly converted into film consumers, it also plays a very important role in the publicity process of the film.

In future, we will open up the whole industrial chain from the original script to the consumer level, and use data to connect with the service providers vertically. The main direction of data-based production is to connect the advertiser's e-commerce with accurate data, extend the upstream and downstream, and give timely feedback.

\section{Diversified financing modes of the film industry}

Traditional film industry financing channels are relatively single, focusing mainly on advertising, bank loans and pre-sale copyright. Famous directors and large-scale productions are often given priority access to these resources. In recent years, the rise of Internet companies has diversified the financing methods of the film industry, and cooperative introduction, joint self-made, brand self-made, investment and production modes have brought innovation in financing. "Online crowdfunding" has become a new method of film financing. Crowdfunding is a convenient and instant financing platform that lets the public participate. Users can contribute any amount to a movie, and get some additional rights and benefits when they give a certain amount, such as meeting their favorite stars in the film crew, visiting the film shoot, etc. At present, the projects of movie crowdfunding available to the public include "entertainment treasure" and "BaifaYouxi," which provide users with a sense of participation. Users can turn their favorite intellectual property (IP) into a movie project without leaving the comfort of their home. Network crowdfunding puts social funds easily into film financing, which to a certain extent breaks the investment monopoly situation of large film and television companies in the film market. It provides opportunities for some minor films and small productions to enter the film market. As a new channel for "Internet +" films in the production process, "Internet public funding" has even played a role in promoting film publicity to a certain extent, and has 
become a "marketing mode under the financing shell." For example, with the help of "entertainment treasure," Alibaba film makes everyone an investor and gain dividends through a small amount of investment, so that financing can penetrate into all links.

\section{Movie script intellectual property (IP)}

For a long time, Chinese films have been faced with the lack of original scripts. The advent of the Internet era has broken the tradition that script production can only be done by professional screenwriters. The production of movie content changes from finding a good script to finding a hot IP. Internet novels, online games, online comics, and online songs are all likely to become a hot IP. IP became a hot word in the film and television industry in 2014, which can be said to be the first year of domestic IP movies. Before that, there was no movie based on existing IP in the domestic film industry. In that year, many major projects announced by film and television companies centered on IP adaptation. For example, Tencent established the film and television business platform "Tencent film +" with high-quality IP as the core, focusing on the adaptation of film IP. Ali film industry also solemnly launched a "popular IP + fan film + celebrity director" mode of film project - Ferryman, which was directed by the famous writer Zhang Jiajia. If 2014 is the year of the birth of IP, then 2015 was the year when the IP battle became increasingly fierce. Major film and television companies not only scrambled for popular IP, but also built IP to become an important direction for major film and television companies to establish diversified business development channels. Looking back at 2015's domestic hot movies, there are 28 film adaptations of Chinese IP, which made nearly 8 billion yuan at the box office, including Goodbye Mr. Loser, Wolf Totem, Mojin - The Lost Legend, Running Man, You Are My Sunshine, Forever Young, and The Left Ear, etc. Among them, Goodbye Mr. Loser, A Hero or Not, and Monkey King: Hero Is Back and other films have won both box office and public praise, and even become the black horse of the annual box office. Due to the high box office capacity of IP films in the summer archives in 2015, major film companies are still optimistic about the influence of the IP boom, so 2016 was still a year of IP content flooding. However, the popularity of IP to the movie spectator seems to have cooled down in 2016. The top six IP films in the total box office are all over 600 million yuan, but only Time Raiders barely exceeded 1 billion yuan. But as the top IP, Time Raiders seems to have less influence than expected. In recent years, IP movies have been almost regarded as the magic weapon of success by the film and television industry, but gradually they seem to be showing some shortcomings. In 2017, after the decline of the IP boom, the online movies are moving forward with highquality products. 


\section{Flexible film screening}

The development of film technology directly determines the level of film productivity, which guarantees the innovation of the screening conditions. The impact of the development of technology on film is obvious. The first benefit is the cinema market. From traditional cinemas to IMAX halls, from $2 \mathrm{D}$ to $3 \mathrm{D}$, a huge market has already been formed in China. Through constantly updating the network terminal, the naked eye $3 \mathrm{D}$ will not be difficult to be put into practice in cinemas. Within the next ten years, 3D holographic images can be projected through mobile devices or an even more sophisticated piece of technology. At the same time, with the progress of science and technology, the content carrier is also transferred from the PC to the mobile. The era of increased broadband will bring the ultimate network speed experience. The coming $5 \mathrm{G}$ technology will stimulate the full popularization of highquality streaming media, and network audio-visual will enter the era of "big video." After Baidu's acquisition of iQiyi and PPS, almost all movie lovers can be satisfied by using these video platforms to show movies; Alibaba film industry is also actively involved in traditional cinema lines, investing in Dadi cinema, trying to create a screening mode that combines online and offline, meeting the viewing habits of different audiences, and realizing no dead ends in watching movies.

\section{Diversification of film derivatives}

At present, the main source of profit in China's film industry is the box office, while in other developed countries, the box office is not as important as other sources of income, as the box office only accounts for one-third of the total income. In addition to the film itself, many other forms of film products have been developed to make profits. The profit model of domestic films will also change dramatically, and the film industry ecosystem, which is comprised of upstream, copyright, midstream, production, promotion, downstream, and derivative market is in full swing. With the development of "Internet +" films, the value of derivatives is once again taken seriously and is involved in the profit link. The products derived from movies, including toys, office supplies, clothing, games, animation, catering, and theme parks, bring new opportunities for the prosperity of the derivative market and improve the film industry chain. With the help of Alibaba, Taobao, and other e-commerce platforms, Alibaba film analyzes the purchase behavior of businesses and users through big data technology, and develops derivatives accurately.

\section{Strategies for the integration of traditional film companies and the Internet industry}

In the face of the development trend of "Internet + " movies, the traditional film companies should follow certain strategies: (1) establish user-oriented 
customization; (2) build a content-based ecosystem; and, finally, (3) promote cross-border operation with the idea of "Internet +."

\section{Establish user-oriented personalized customization}

In the Internet age, personalized movies and accurate user groups can improve the loyalty of users and extend their influence. In recent years, users' demand for different works has grown, aesthetic requirements have improved, and more fresh content is needed to stimulate the senses. This requires us to be user-oriented, have the ability to predict, find the needs through data, meet the needs through a variety of services, and create needs through personalized recommendations. Traditional film and television companies can only make steady progress in the Internet era if they focus on subdividing content and identifying users.

\section{Build an ecosystem supported by content}

In the 100 years of film development, every technological advance has brought a new sensory experience to the audience. But movies are always supported by content. Traditional film companies can use projects to tap deeply into the social and commercial value of the story and maximize the value of the content. The Internet has changed people's consumption mode and service concept, but that does not change the essence of the movie. The movie also needs high-quality content as support. For example, the domestic animated film, Monkey King: Hero Is Back, released in the summer of 2015 is adapted from the old IP Journey to the West, but it retells the classic tale in a unique way which gets audiences interested, resulting in a huge profit at the box office. High quality content is the foundation of the sustainable development of domestic films. Instead of buying IP blindly, it's better to build a new IP with real value.

\section{Promoting cross-border operations with the idea of "Internet +"}

In the era of "Internet +," the boundaries between industries are blurred, and movies interact with other industries in depth. Cross-border marketing can make movies popular in a short time, extend the industrial chain and expand the profit space. Traditional film companies should break the boundaries of branding, publicity and platform, and develop high-quality integrated products. To some extent, this will change the marketing mode of domestic films, which focuses on box office earnings, and make the profit mode of films more diverse and effective.

The advent of the Internet era has brought new opportunities and challenges to the development of China's film industry. It has reshaped film production, distribution, projection, and marketing. Through this change, the traditional film industry can only achieve leaps in development by putting the users first, giving priority to content, and taking "Internet plus" as the pattern to follow. 